\title{
SH2B1 wt Allele
}

National Cancer Institute

\section{Source}

National Cancer Institute. SH2B1 wt Allele. NCI Thesaurus. Code C52415.

Human SH2B1 wild-type allele is located in the vicinity of $16 \mathrm{p} 11.2$ and is approximately 27

$\mathrm{kb}$ in length. This allele, which encodes SH2B adaptor protein 1, is involved in the regulation of multiple growth factor-mediated signaling pathways. 